Nevşehir Bilim ve Teknoloji Dergisi (2019), 8(2) 114-124

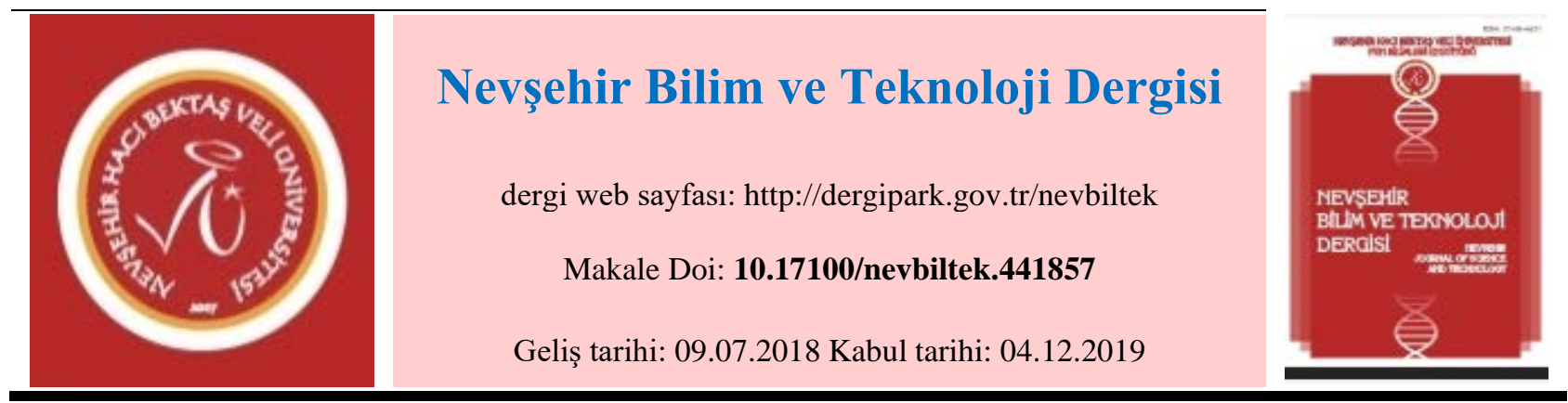

\title{
Ağaç Malzemelerin Daire Testere Makinelerinde İşlenmesinde Testere Geometrisi ve Uygulama Koşullarının Önemi ${ }^{1}$
}

\author{
Ali ÇAKMAK ${ }^{1}$, Abdulkadir MALKOÇOĞLU² \\ ${ }^{1}$ Karadeniz Teknik Üniversitesi, Orman Fakültesi, Orman Endüstri Mühendisliği Bölümü, Trabzon \\ ORCID ID: 0000-0002-0827-022X \\ ${ }^{2}$ Karadeniz Teknik Üniversitesi, Orman Fakültesi, Orman Endüstri Mühendisliği Bölümü, Trabzon \\ ORCID ID: 0000-0003-2416-5099
}

\begin{abstract}
Özet
Daire testere makineleri genellikle bir yüzeyi ve kenarı düzeltilmiş parçaların istenilen ölçü ve açılarda boyutlandırılmasında, levha ölçülendirilmesinde, kanal, kiniş ve birleştirme yeri açılması vb. işlemlerde kullanılmaktadır. Bu amaçla, işlemede testere seçiminin; ürün kalitesi ve verimlilik bakımından çok önemli olduğu ortaya konulabilir. Testere seçimini etkileyen temel faktörler; malzeme yoğunluğu ve rutubeti, kesici uç malzeme tipi ve şekli ile kesme ve kama açısı olarak belirtilebilir. Bu çalışmada, ağaç malzemelerin daire testere makinelerinde işlenmesinde; testere kesici geometrisi ve seçimi ile işlemeyi etkileyen faktörler üzerinde durulmuştur. Aynı zamanda, ölçülendirme işlemlerinde daire testerelerde karşılaşılan sorunlar ve çözüm önerileri belirtilmiştir.
\end{abstract}

Anahtar Kelimeler: Daire testere geometrisi, Testere seçimi, Daire testere makinesi

\section{Importance of Saw Blade Geometry and Technic Conditions in Machining of Wood Materials in Circular Saw Machines ${ }^{1}$}

\begin{abstract}
Circular saw machines are usually used for cutting of the edge flattened parts to desired dimensions and angles, sizing of panels, grooving, jointing, rebating, etc. For this purpose, it can be stated that the selection of the cutter in machining is very important in terms of product quality and efficiency. It can be indicated that the main factors affecting saw blade selection are material density and humidity, cutting edge shape and type with rake and tool angle. In this study, saw blade geometry, its selection and factors affecting the process were studied in the machining of wood materials in circular sawing machines. Also, the problems and solutions proposal encountered in the circular saws during in sizing are stated.
\end{abstract}

Keywords: Saw Blade Geometry, Saw Blade Selection, Circular Saw Machine.

\footnotetext{
${ }^{1} \mathrm{Bu}$ çalışma, Giresun Üniversitesinde 27-29 Haziran 2018 tarihinde düzenlenen 1. Uluslararası Teknoloji Bilimleri ve Tasarım Sempozyumunda sunulmuştur.

Sorumlu yazar e-mail: alicakmak@ktu.edu.tr
} 


\section{Introduction}

No cutting method or type actually cuts the materials. The process occurs as a result of force application of the blade and structural degradation of the materials. Degradations in the process are impressed by section (tangential, radial and longitudinal), different tree species, fiber orientation, moisture content and resistance properties of the wood. Same way; the construction of cutting tools and machines and their operations are closely related to the level of occurrence of defects in machining of wood materials [1-5]. The production cost of any product is quite efficient in machining. In this context, it is stated that the share of the machining in furniture production cost is $23 \%$ [6-8].

Wood is one of the most precious and difficult engineering materials of the mankind. Although it is light, it is a material that has a high resistance to various effects, easily processed and consumes less energy during machining. Traditionally, it has been used as the main raw material for centuries in production of furniture, joinery, interior design, wood structures, paper, packaging, transportation, toys, various tools, etc. [9-11]. Nowadays, various low-priced industrial panels (MDF, chipboard, plywood and laminated wood-based materials, etc.) are used instead of wood in these productions [12-19].

Circular saws are widely used in the machining of wood materials, especially in traditional and computerized machines in the furniture industry. There are many kinds of these in terms of the number of teeth, tooth form and material and the machining conditions. For this reason, it can be stated that the choice of saw blade is so important in terms of capacity, efficiency and end-product quality [9, 20-24]

In this study, saw blade geometry, selection and factors affecting the machining were studied in the machining of wood and wood-based materials in circular sawing machines. Also, the problems and solutions proposal encountered in the circular saws during in sizing are stated.

\section{Literature}

\subsection{Functions of Circular Saw Machines}

Circular saw machines are usually used in grooving, mortising, tenoning and cutting the length, width and thickness of surfaces and edges flattened parts to the desired dimensions and angles in machining of wood and woodbased materials. Various machines and saw blades that have many different types and technical specifications are used for many operations. These are single or doubled circular saws. Parts are one by one in single sawed type, and one or more in doubled type depending on the size of the parts (Fig. 1) [22, 23, 25-28].

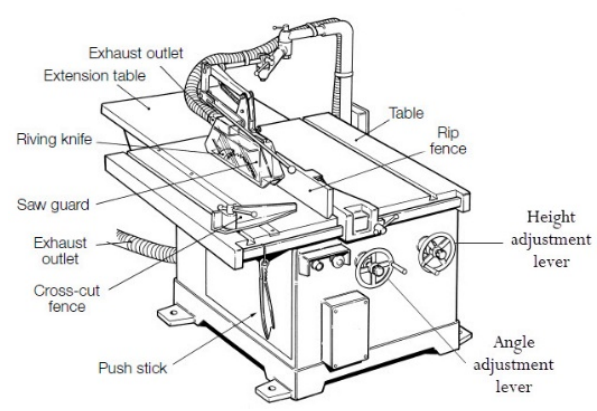

Fig. 1. Basic parts of a circular saw machine (29).

\subsection{Factors Effecting Machining Quality}

The conditions necessary for proper machining of wood materials are generally examined in three main groups [5, 30]:

I. Mechanical condition of knives or cutting tools: These contain especially cutters associated with tools or machine parts (machine maintenance, cutting material and tooth form, placement of cutting tools on the machine, wedge angle and sharpness of the cutter) 


\section{Nevşehir Bilim ve Teknoloji Dergisi (2019), 8(2) 114-124}

II. Adjustment and operation of tools or machines: It usually occurs from four parts which directly affect the surface quality in machining (hook/rake angle, cutting depth, feed and cutting speed and tooth pitch in unit length)

III. Structure and characteristics of wood material: These are moisture content, density, growth rate of wood material or annual number of rings, latewood participation rate and wood defects.

The lack of fulfillment of the various conditions in these factors, or ignorance in the selection, directly affects the machining and hence the surface quality. According to the rules stated here with maintaining proper machining conditions.; it is ensured that the various wood material surfaces are obtained as least defects [3, 5, 30-33].

The importance of factors related to cutting and feed speeds, material and cutters are emphasized based on the surface quality.

According these, it is stated that smooth surfaces are obtained with lower feed speed and higher cutting speed and machining performance increases in low rake angles. It is suggested lower rake angle (According to American Society for Testing and Materials-ASTM) for high density woods and higher rake angle for low density woods (Table 1) [34-38].

Table 1. Optimum hook/rake angles for some wood species in machining [34-38].

\begin{tabular}{|l|c|c|}
\hline Wood Species & $\begin{array}{c}\text { Hook/Rake } \\
\text { Angle }\left(^{(}\right)^{*}\end{array}$ & $\begin{array}{c}\text { Moisture } \\
\text { Content } \\
(\%)\end{array}$ \\
\hline Lime tree & 25 & 6 \\
\hline Elm & 15 & 6 \\
\hline Alder (soft) & 20 & 6 \\
\hline Alder (hard) & 15 & 6 \\
\hline Oak & 10 & 6 \\
\hline Oriental beech & 15 & 12 \\
\hline Anatolian chestnut & 15 & 12 \\
\hline White alder & 15 & 12 \\
\hline Scotch pine & $15-20$ & 12 \\
\hline Oriental spruce & $15-25$ & 12 \\
\hline Oriental beech & 15 & 12 \\
\hline
\end{tabular}

* According to ASTM

\subsection{Circular Saw Machines and Machining Quality}

The machining quality in circular saws can generally be stated according to the factors affecting surface quality. These are structure and characteristics of wood, geometry and technical specifications of circular saw blade (saw blade diameter, number of teeth, gullet, cutting edge type and rake angle) and machining conditions (feed and cutting speeds).

\subsubsection{Structure and Characteristics of Wood}

One of the most important factors in the selection of circular saw blade is making a choice according to the material to be machined in machining process. Investigations on the surface quality effect of wood moisture and density have generally indicated that smoother surfaces are obtained with better machining conditions in high density and low moisture woods. On the other hand, moisture reduces the machining quality by plasticizing the wood and compressing the wood during the process [5, 30, 36].

\subsubsection{Geometry and Technical Specifications of Circular Saw Blades}

There are many circular saw blades that have very different brands and technical specifications in terms of material, cutter properties and processing conditions. These properties are generally the number of teeth, cutting edge type and width, rake angle, saw blade and flange diameter, saw blade thickness, material type, expansion, cooling and sound insulation slots. Flange diameter varies depending on the diameter of the circular saw (Fig. 2). 
Nevşehir Bilim ve Teknoloji Dergisi (2019), 8(2) 114-124

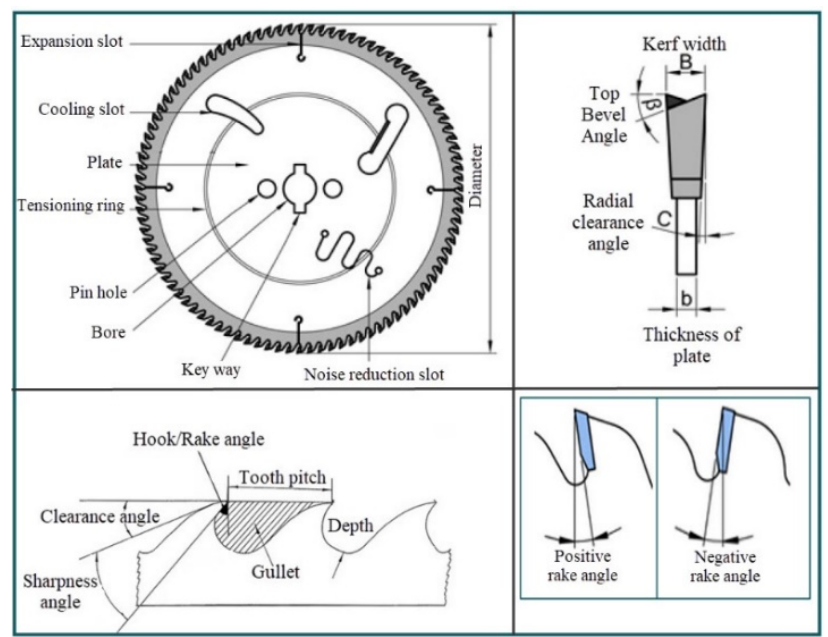

Fig. 2. Basic geometry of a circular saw blade [39, 40]

In the machining of wood materials in circular saw machines four tooth forms as straight, bevel, trapezoidal, conical and their combinations are commonly used (Fig. 3).

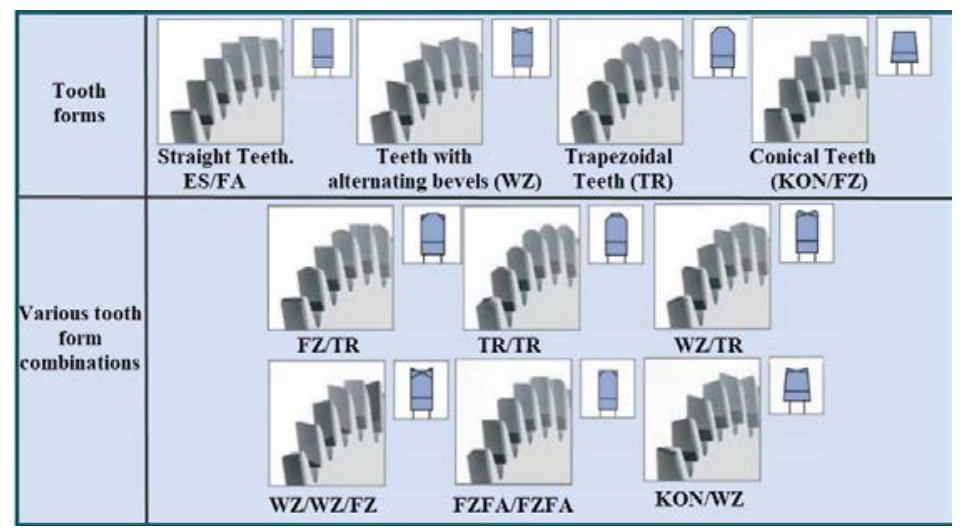

Fig. 3. Commonly used tooth forms [41-43].

Straight tooth form is usually used in timber construction industry at high speeds and when an average surface quality is desired in the rip and cross cutting (transverse cutting) processes. Bevel tooth form is used in machining of glued or non-glued wood materials and veneered and laminated wood-based materials, plywood and non-ferrous metals. Trapezoidal tooth form is used in the dimensioning and grooving processes of wood-based materials. Conical tooth form is especially used in scoring saw blades for veneered and laminated wood-based materials. Besides, these saws can also be used with various tooth form combination. In a study, it was proposed to use WZ tooth formed circular saw with 28 teeth for the processing of pine, beech, fir and oak wood species [42-45].

Tungsten carbide (HW) and high-speed steels (HSS) cutting materials are commonly used in the dimensioning of wood materials. In addition, monocrystalline and polycrystalline (DM and DP/CVD) diamond cutters are often used in the machining of solid woods, fibre and chipboards, laminate floors, fibre cement boards, reinforced plastics and nonferrous metals in a wide range.

\subsubsection{Machining Conditions}

One of the most important factors after the selection of the saw is the choice of processing conditions. The technical specifications of the circular saws and the operations to be carried out according to the material type require different feed and cutting speed rates. Today, relationships between desired tooth pitch, number of teeth and machining conditions for circular saws are presented as table and charts (Fig. 4) [42-44]. 


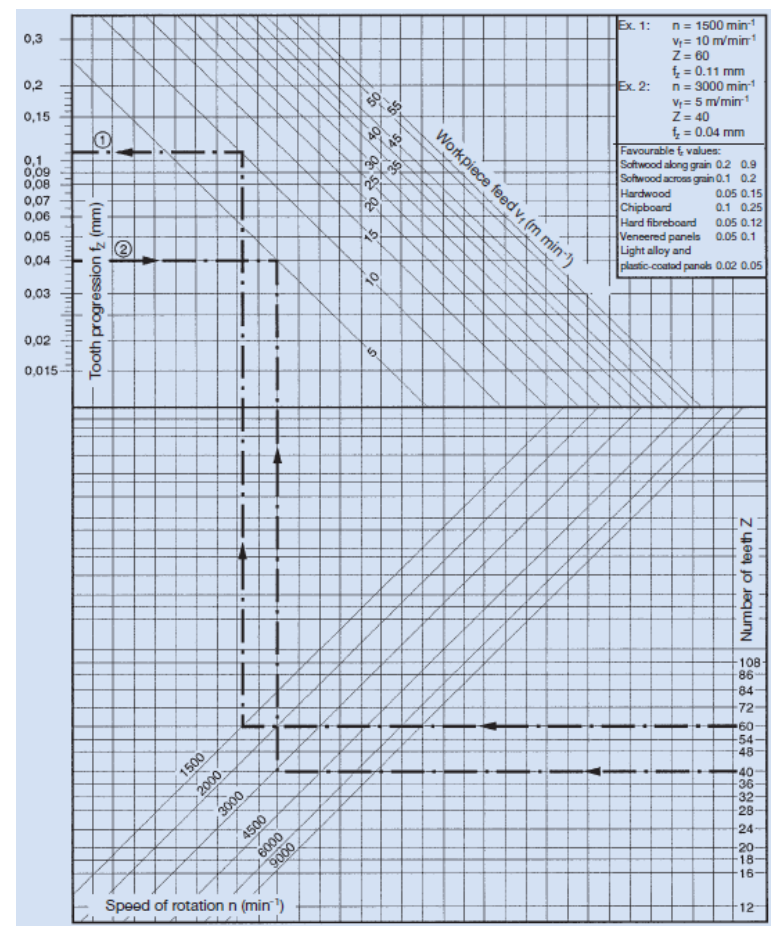

(a)

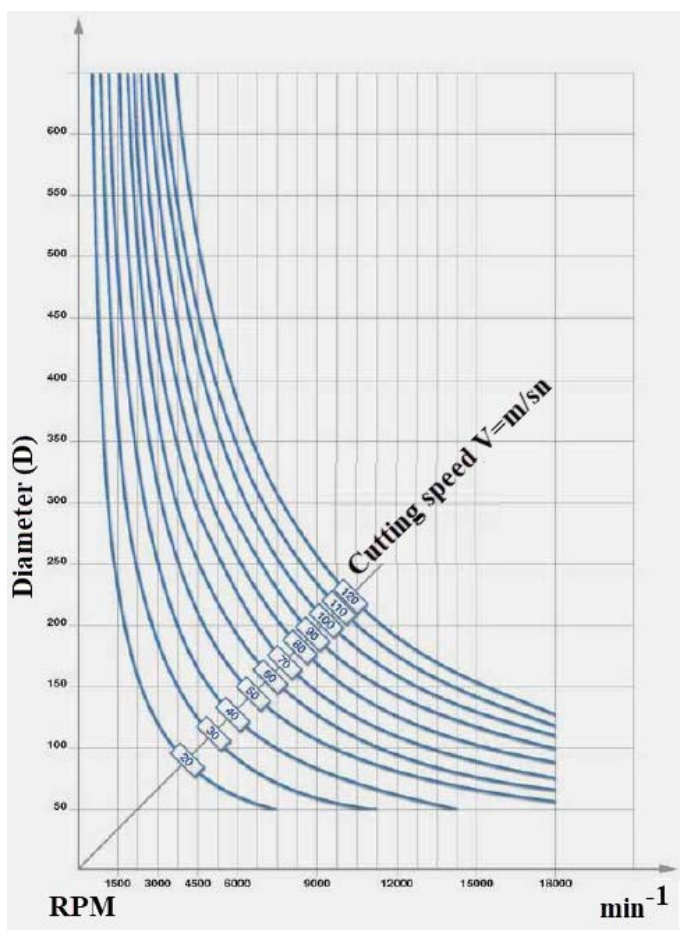

(b)

Fig. 4. Relationships between RPM, feed rate, number of teeth (a) and diameter-cutting speed (b) [42, 43].

As shown in Figure 4, various feed rates can be selected based on the different range of RPM for number of teeth and cutting material. Thus, products of various qualities can be obtained with different tooth pitches in relation to the capacity. At the same time cutting speed increases with the increase of saw blade diameter.

In the machining in circular saw machines, smoother surfaces are obtained in the radial direction. In addition, increasing the number of teeth and decreasing the feed speed, it is stated that smoother surfaces can be obtained and the number of teeth in dense materials should be increased [35, 44, 46, 47].

In terms of power consumption in circular saw machining; it can be stated that the choice of saw geometry shape, number of teeth, rake angle etc.), feed rate, cutting speed and cutting power are the most important factors on reducing time and power consumption. As tool wear increases, cutting force and power consumption also increases [48, 49]. Power consumption increases with the increase of feed rate, cutting speed and clearance of the sawblade. It was stated that there was not a linear relation between the cutting power and rotation speed. Climb sawing is required more power than counter sawing in terms of cutting processes. At the same time, HSS blades have more impact on power consumption than HW and DP blades [50-55].

\section{Saw Blade Selection in Machining of Wood Materials in Circular Saw Machine}

In wood machining, the "volume increase factor" in chip formation ranges from 1.5 to 7.5. This amount depends on the type of wood, moisture content and rake angle. For this reason, these factors should be considered when choosing circular saw blades $[9,35,44]$.

In machining of wood materials in circular saw machine; the volume increase factor is lower in broad-leaved tree woods and across the grain direction in contrast to coniferous woods and the along the grain direction. Accordingly, the number of teeth should be less and the gullet should be larger in the machining with circular saws in along the grain direction. At the same time, the rake angle is higher than the circular saws used in across the grain direction. These saws are generally 180-250 mm in diameter, and the number of teeth should be chosen less in comparison with the machining 


\section{Nevşehir Bilim ve Teknoloji Dergisi (2019), 8(2) 114-124}

in across the grain direction (Table 2 and Fig. 5). In the machining in across the grain direction, the number of teeth should be more and the gullet must be smaller. Rake angle should be selected lower and saw diameter should be selected higher in comparison with the machining in along the grain direction [9, 35, 47, 49].

Table 2. Some technical specifications of circular saw blades used in the machining in across and along the grain direction [41-43, 56, 57].

\begin{tabular}{|c|c|c|c|c|c|c|c|}
\hline $\begin{array}{c}\text { Grain } \\
\text { direction }\end{array}$ & $\begin{array}{c}\text { Cutting } \\
\text { material }\end{array}$ & $\begin{array}{c}\text { Diameter } \\
(\mathrm{D}) \\
(\mathrm{mm})\end{array}$ & $\begin{array}{c}\text { Kerf } \\
\text { width } \\
(\mathrm{SB})(\mathrm{mm})\end{array}$ & $\begin{array}{c}\text { Thickness } \\
\text { of plate } \\
(\mathrm{TDI})(\mathrm{mm})\end{array}$ & $\begin{array}{c}\text { Number } \\
\text { of teeth } \\
(\text { Piece })\end{array}$ & Tooth form & $\begin{array}{c}\text { Hooh/Rake } \\
\text { angle } \\
\left({ }^{(}\right)\end{array}$ \\
\hline Along grain & HW & $180-250$ & $1.3-4$ & $0.9-2.8$ & $21-40$ & $\begin{array}{c}\mathrm{FZ} \\
\text { FZ/WZ }\end{array}$ & $10,15,20$ \\
\hline Along grain & DP & $180-200$ & 3.2 & 2.2 & $24-48$ & $\mathrm{FZ}$ & 10 \\
\hline Across grain & HW & $300-630$ & $2.4-5.8$ & $2.4-3.5$ & $36-180$ & $\begin{array}{c}\mathrm{WZ} \\
\text { WZ/WZ/FZ }\end{array}$ & $-5,10,15$ \\
\hline Across grain & DP & $250-350$ & 3.2 & 2.4 & $50-70$ & WZFA & 10 \\
\hline
\end{tabular}

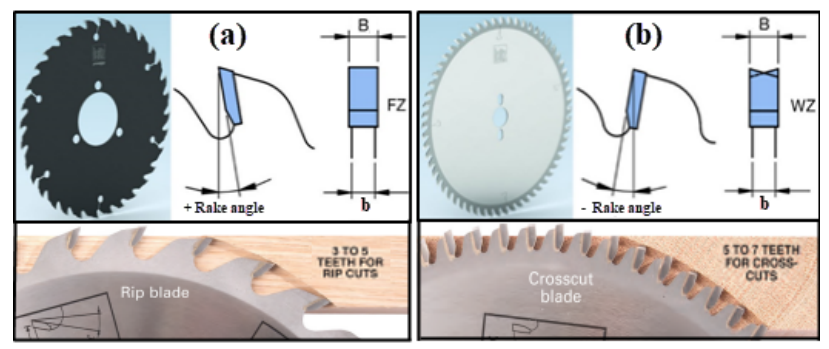

Fig. 5. Circular saw blades used in along (a) and across the grain (b) direction [43, 50, 58].

The saw blade selection should be made considering the fact that the wood-based materials have various densities, glue content and coating materials. For this purpose, a great variety of saw blades are used. These have different diameters, number of teeth and tooth forms. It was stated that there is no significant difference in the measured noise level for saw blades with 40 and 60 teeth and the blade with the fewest number of teeth has a shorter lifetime in a study. The fact that the saw diameter is bigger, number of teeth more and feed speed less is very effective in terms of machining efficiency and surface roughness in selection of saw blade in the machining of high-density materials (Table 3). It is possible to increase the capacity and to obtain quality products by reducing the processing costs by selecting the appropriate tools [9, 35, 47, 53, 59].

Table 3. Some technical specifications of circular saw blades used in the machining of wood and wood-based materials [41-43, 56, 57].

\begin{tabular}{|l|l|c|c|c|c|c|c|}
\hline Process & $\begin{array}{c}\text { Cutting } \\
\text { material }\end{array}$ & $\begin{array}{c}\text { Diameter } \\
\text { (D) } \\
(\mathrm{mm})\end{array}$ & $\begin{array}{c}\text { Kerf } \\
\text { width } \\
\text { (SB) } \\
(\mathrm{mm})\end{array}$ & $\begin{array}{c}\text { Thickness } \\
\text { of plate } \\
\text { (TDI) } \\
\text { (mm) }\end{array}$ & $\begin{array}{c}\text { Number } \\
\text { of teeth } \\
\text { (Piece) }\end{array}$ & $\begin{array}{c}\text { Tooth } \\
\text { form }\end{array}$ & $\begin{array}{c}\text { Hooh/Rake } \\
\text { angle } \\
\left({ }^{\circ}\right.\end{array}$ \\
\hline Sizing & HW & $250-750$ & $3.2-7$ & $2.2-5$ & $48-72$ & $\begin{array}{c}\mathrm{WZ} \\
\mathrm{FZ} / \mathrm{TR} \\
\text { TR/TR }\end{array}$ & $10,15,22$ \\
\hline Sizing & DP & $300-450$ & $4.4-4.8$ & $3.2-3.5$ & $60-72$ & TR/TR & 10 \\
\hline Scoring & HW & $100-300$ & $3.2-6.8$ & $2.5-4.2$ & $24-72$ & KON/WZ & 5 \\
\hline Scoring & DP & $125-200$ & $3.1-4.7$ & $2.5-3.5$ & $20-30$ & KON/WZ & 10 \\
\hline
\end{tabular}

Circular saw blade geometry is the most significant factor that effects its strength. It should be considered that it can be broken on weak points like between the outer slot and the key. It was recommended to use a circular saw blade with the slots rotated by $45^{\circ}[24,49]$. 
Nevşehir Bilim ve Teknoloji Dergisi (2019), 8(2) 114-124

\section{Problems and Proposed Solutions Encountered with Sizing Operations}

Many problems are encountered with saw blades used in sizing operations of wood and wood-based materials in circular saw machines in furniture, joinery, and wooden construction industries etc. These problems and proposed solutions are stated in Table 4.

Table 4. Problems and proposed solutions encountered with saw blades used in sizing operations [6, 7, 9, 41-43].

\begin{tabular}{|c|c|c|}
\hline Problems & Causes & Precautions \\
\hline Sawblade wobbles & $\begin{array}{l}\text { 1. Too high flange tolerance, low } \\
\text { thickness of tool and tooth projection or } \\
\text { residuals on the flanges. } \\
\text { 2. Selection of wrong sawblade or } \\
\text { spindle. }\end{array}$ & $\begin{array}{l}\text { 1. Select a smaller diameter sawblade, increase } \\
\text { flange diameter and check flanges if they are } \\
\text { correct and clean or not. } \\
\text { 2. Select a more feasible sawblade or spindle (in } \\
\text { terms of tooth pitch, sharpness, tensioning and } \\
\text { bearing) and check balance. }\end{array}$ \\
\hline Sinuous cut & $\begin{array}{l}\text { Selection of wrong sawblade geometry } \\
\text { and machining conditions. }\end{array}$ & $\begin{array}{l}\text { Select a more feasible sawblade (in terms of } \\
\text { diameter, tooth pitch and thickness, kerf and } \\
\text { sharpness) and check machining conditions (cutting } \\
\text { speed, feed speed and direction) }\end{array}$ \\
\hline $\begin{array}{l}\text { Squeezing of } \\
\text { sawblade in operations }\end{array}$ & $\begin{array}{l}\text { Too big saw bed, too small gullets and } \\
\text { insufficient chip flow and riving knife } \\
\text { width. }\end{array}$ & $\begin{array}{l}\text { Change saw bed and riving knife and use sawblade } \\
\text { with larger gullet. }\end{array}$ \\
\hline $\begin{array}{l}\text { Scoring saw cuts } \\
\text { defective and doesn't } \\
\text { work at same direction } \\
\text { with main sawblade }\end{array}$ & $\begin{array}{l}\text { 1. Scoring saw is blunt working wavy. } \\
\text { 2. Both main and scoring sawblade or } \\
\text { flanges are working wavy. } \\
\text { 3.There are residuals on the flanges or } \\
\text { dusted. }\end{array}$ & $\begin{array}{l}\text { 1. Check scoring saw adjustment or change it. } \\
\text { 2. If it is necessary, change spindle bearing. } \\
\text { 3. Clear flanges. }\end{array}$ \\
\hline $\begin{array}{l}\text { Measurement faults in } \\
\text { miter cuts }\end{array}$ & $\begin{array}{l}\text { 1. Fence bolt is loosened or dusted } \\
\text { 2. Interlocking elements of fence are } \\
\text { corroded. }\end{array}$ & $\begin{array}{l}\text { 1. Jam the bolt with proper spanner and eliminate } \\
\text { the gap or clean it. } \\
\text { 2. Renew elements. }\end{array}$ \\
\hline $\begin{array}{l}\text { Curved cut when } \\
\text { double edging }\end{array}$ & $\begin{array}{l}\text { Sharpness of sawblade, residuals on } \\
\text { rollers, short workpieces, irregularities in } \\
\text { wood thickness and cutting force. }\end{array}$ & $\begin{array}{l}\text { Make sure sharpening is two sided, clean rollers, } \\
\text { comply with minimum available workpiece length } \\
\text { by instructions and be attentive to select optimized } \\
\text { cutting force. }\end{array}$ \\
\hline $\begin{array}{l}\text { Defects in coated } \\
\text { workpieces on both } \\
\text { sides }\end{array}$ & $\begin{array}{l}\text { 1. Sawblade projection over workpiece is } \\
2-3 \mathrm{~mm} \text {. } \\
\text { 2. Scoring saw is not used. } \\
\text { 3.Selection of wrong sawblade geometry } \\
\text { and improper flange diameter. } \\
\text { 4. Insufficient pressure on workpiece. }\end{array}$ & $\begin{array}{l}\text { 1. It is more feasible to use } 2-3 \mathrm{~cm} \text { for sawblade } \\
\text { projection over workpiece. } \\
\text { 2. Use proper scoring saw (kerf has to proper with } \\
\text { main sawblade). } \\
\text { 3. Select correct tooth form, number of teeth and } \\
\text { flange diameter for the application and check } \\
\text { sharpness of sawblade. } \\
\text { 4. Increase pressing force on workpiece. }\end{array}$ \\
\hline
\end{tabular}

\section{Results and Suggestions}

Saw blades should be selected in view of the fact that the factors as material, cutting tools and machine in machining of wood and wood-based materials in circular saw machines. First of all, the density of material to be processed, moisture content and grain direction must be considered in choosing of a saw blade. Accordingly, the results can be summarized as follows:

I. In high density woods and machining in the across the grain direction; the number of teeth and saw diameter should be more; the gullet should be smaller and the feed and cutting speed with the rake angle (According to ASTM) should be low.

II.. In wood with high moisture content; the number of teeth should be less, the larger gullet should be selected, feed and cutting speed should be preferred lower.

III. The cutting speed should also be increased as the saw diameter increases. Saw blades should be used in proper cutting speed (rpm) noted in manufacturer catalogue.

IV. Straight tooth form should be preferred when an average surface quality is desired in the along and across the grain direction. Bevel tooth form can be used in machining of veneered and laminated wood-based materials and non- 
Nevşehir Bilim ve Teknoloji Dergisi (2019), 8(2) 114-124

ferrous metals. Trapezoidal tooth form can be used in the sizing of wood-based materials and conical tooth form should be considered in scoring saw blades for veneered and laminated wood-based materials.

V. According to the cutting material type; HSS and HW can be preferred for a general use in dimensioning, mortising, tenoning etc. of wood materials; HW can be used for machining of industrial panels, soft and hard woods with coated veneered panels and DP should be used in machining of industrial panels, plastics, nonferrous metals and hardwoods. However, the use of DP should be avoided in very hard knotted conifer trees.

VI. Sawblades with built-in vibration and noise reduction slots should be choice for reducing of noise during processing in terms of work safety.

The selection of saw blade in heterogeneous wood and wood-based materials is rather important and difficult in terms of product quality, efficiency and power consumption. In this respect; considering the factors affecting the surface quality, selection of saw blade geometry and machining conditions, using of the cutter firm catalogs and academic studies can be recommended for the variable applications and most suitable choices. In future works, the effect of saw geometry selection on surface quality and power consumption can be investigate more extensively.

\section{References}

[1] Davim, J.P. 2011. “Wood machining”, ISTE Ltd and John Wiley \& Sons, Inc., London.

[2] Wengert, G. 1998. "Rx for Wood Machining Defects: Wood processing”, Department of Forestry, University of Wisconsin-Madison, Woodweb, Virginia.

[3] Koch, P. 1972. "Utilization of The Southern Pines”, Department of Agriculture Forest Service. Handbook (420), 53463.

[4] Kollmann, F. F., Côté Jr, W. A. 1968. "Principles of Wood Science and Technology. Vol. I. Solid Wood”, SpringerVerlag. Berlin.

[5] Davis, E. M. 1962. "Machining and Related Characteristics of United States Hardwoods", Technical Bulletin No: 1267, US Department of Agriculture-Forest Service, Washington, DC.

[6] Malkoçoğlu, A., 2017. “Ağaç Malzeme İşleme Teknikleri Basılmamış Ders Notları”, KTÜ. Orman Fakültesi, Trabzon.

[7] Malkoçoğlu, A., Tiryaki, S. 2011. “Ağaç Malzemelerin İşlenme Esasları”, Mobilya Dekorasyon Dergisi, 101, 158174.

[8] Hoff K, Fisher N, Miller S, Webb A. 1997. "Sources of Competitiveness for Secondary Wood Products Firms: A Review of Literature and Research Issues”, Forest Prod. J. 47(2): 31-37.

[9] Malkoçoğlu, A., 2018. "Mobilya Endüstrisi Basılmamış Ders Notları”, KTÜ. Orman Fakültesi, Trabzon.

[10] Csanády, E., \& Magoss, E. 2012. “Mechanics of Wood Machining”, Springer, Verlag Berlin Heidelberg.

[11] UNIDO, 1989. "Furniture and Joinery Industries for Developing Countries", United Nations Industrial Development Organization, Vienna.

[12] Kaplan, L., Kvietková, M. S., Sedlecký, M. 2018. "Effect of the Interaction Between Thermal Modification Temperature and Cutting Parameters on the Quality of Oak Wood”, BioResources, 13(1), 1251-1264.

[13] Gottlöber, C., Wagenführ, A., Röbenack, K., Ahmed, D., Eckhardt, S. 2016. “Strategies, Concepts and Approaches to Avoid Cuttermarks On Wooden Workpiece Surfaces”, Wood Material Science \& Engineering, 11(3), 147-155.

[14] Gaff, M. 2014. “Three-Dimensional Pneumatic Molding of Veneers” BioResources, 9(3), 5676-5687 
Nevşehir Bilim ve Teknoloji Dergisi (2019), 8(2) 114-124

[15] Kurtoğlu A., Sofuoğlu S. D. 2013. “Mobilya ve Ağaç İşlerinde Kullanılan Ahşap Malzemeler 1”, Mobilya Dekorasyon Dergisi, Eylül-Ekim.

[16] Kurtoğlu A., Sofuoğlu S. D. 2013. "Mobilya ve Ağaç İşlerinde Kullanılan Ahşap Malzemeler 2: Kapı ve Pencere Yapımında Ağaç Malzemenin Kullanılması”, Mobilya Dekorasyon Dergisi, Kasım-Aralık, 119, 52-66.

[17] Eroğlu, F. 2007. “Ankara Mobilyacılar Sitesinde Faaliyet Gösteren Küçük ve Orta Ölçekli Mobilya İşletmelerinin Analizi ve Çözüm Önerileri”, Fen Bilimleri Enstitüsü, Yüksek Lisans Tezi, Gazi Üniversitesi.

[18] Kurtoğlu, A. 2000. “Ağaç Malzeme Yüzey İşlemleri”, Cilt 1, İstanbul Üniversitesi Orman Fakültesi, Üniv. Yayın No: 4262, Fak. Yayın No: 463, İstanbul.

[19] Erdinler, E. S. 2005. “CAD Sistemleri ve Türkiye Mobilya Endüstrisinde Uygulanma Etkinliğinin Analizi”, Fen Bil. Enstitüsü Doktora Tezi, İstanbul Üniversitesi.

[20] Anonymous, 2017. "Weinig Group”, Weinigstraße 2/4, 97941 Tauberbischofsheim, Germany, https://www.weinig.com.

[21] Mitchell, P. H., Wiedenbeck, J., Ammerman, B. 2005. "Rough mill improvement guide for managers and supervisors”, USDA Forest Service, Newton Square, USA.

[22] Burdurlu, E., Baykan İ., 1998. "Ağaç İşlerinde Kesme Teorisi ve Endüstriyel Mobilya Üretimi Makineleri”, Hacettepe Üniversitesi Yayınları, Ankara.

[23] İlhan, R., Burdurlu E., Baykan İ., 1990. “Ağaç İşlerinde Kesme Teorisi ve Mobilya Endüstrisi Makineleri”, Hacettepe Üniversitesi Yayınlarl, Ankara.

[24] Bílek, O., Šuba, O., \& Bad’urová, J. 2018. “A numerical simulation of static stiffness and strength of circular saw blade”, In MATEC Web of Conferences (Vol. 210, p. 04031). EDP Sciences.

[25] Chabrier, P., Martin, P. 1999. "Industrial Point of View on Straightening and Tensioning of Circular Saw Blades”. 14th Int. Wood Machining Seminar, Paris, Epinal, Cluny, 1, 137-143.

[26] Renshaw, A. 1999. "Centripetal Tensioning for High Speed Circular Saw”. 14th Int. Wood Machining Seminar, Paris, Epinal, Cluny, 1, 129-135.

[27] Schajer, G.S., Wang, S. 1999. "Effect of Workpiece Interaction on Circular Saw Cutting Stability”. 14th Int. Wood Machining Seminar, Paris, Epinal, Cluny, 1, 173-185.

[28] Lehmann, B.F., Hutton, S.G. 1997. "The Mechanics of Bandsaw Cutting. Part II. A Simulation of The Cutting Behaviour Of Bandsaws”. Holz als Roh- und Werkstoff, 55: 35-43

[29] HSE, 2018. "Circular Saw Benches-Safe Working Practices: Health and Safety Executive”, British Standards Institution, Chiswick/London.

[30] Kurtoğlu, A., 1981. “Odunun İşlenme Özellikleri”, İstanbul Üniversitesi Orman Fakültesi Dergisi, Seri: B, Cilt: 31 (2).

[31] Ratnasingam, J. Ma T.P., Perkins M.C. 1999. "Productivty in Wood Machining Processes; A Question of Simple Economics”, Holz Als Roh-und Werktoff, 57, 51-56.

[32] Smith, P., H.O., Ma. 1990. “The Global Wooden Furniture Industry: An Emphasis on The Pacificrim”. CINTRAFOR, Working Paper 25, University of Washington, Seattle, Washington.

[33] Koch P. 1964. "Wood Machining Processes; A Volume in The Wood Processing Series”, New York: The Ronald Press Company, p. 530. 
Nevşehir Bilim ve Teknoloji Dergisi (2019), 8(2) 114-124

[34] Sofuoglu, S. D. 2016. "Determination of Optimal Machining Parameters of Massive Wooden Edge Glued Panels Which Is Made of Scots Pine (Pinus Sylvestris L.) Using Taguchi Design Method." European Journal of Wood and Wood Products: 1-10.

[35] Sönmez, A., Söğütlü, C. 2009. "Biçme İşleminde Kesiş Yönü ve Daire Testere Diş Sayısının Ağaç Malzeme Yüzey Pürüzlülüğüne Etkisi”, Politeknik Dergisi, 12(1).

[36] Malkoçoğlu A. 2007. "Machining Properties and Surface Roughness of Various Wood Species Planed in Different Conditions", Building and Environment, vol.42, pp.2562-2567.

[37] Malkoçoğlu A., Özdemir T., Arz N. 2007. "Mobilya ve Doğrama Endüstrilerinde Ahşap Malzemenin Kullanımı ve Özellikleri", Mobilya Dekorasyon Dergisi, cilt.78, ss.136-144.

[38] Williams, D. and Morris, R., 1998. "Machining and Related Mechanical Properties of 15 B.C”. Wood Species, Forintek Canada Corp.

[39] URL-1: http://www.chinasawblade.com/technical.asp (E.T.:22.09.2019).

[40] URL-2:http://www.irwin.com/uploads/products/brochure/7_2013_CSB_eBook.pdf (E.T.: 22.09.2019).

[41] Bosch, 2018. “Top Precision: Daire Testereler Kataloğu”, Robert Bosch GmbH, Germany.

[42] Bilteks, 2018. “Testere Ürün Kataloğu”, İTOB Organize Sanayi Bölgesi 10023 Sk. No:11 Tekeli, Menderes, İzmir.

[43] Leitz, 2017. “Precision tables by Leitz, The Leitz-Lexicon Edition 7”, GmbH \& Co. KG., Germany.

[44] Demirci, S., Kılıç, Y. 2005. "Daire Testerelerde Diş Sayısı ve Besleme Hızının Ceviz (Juglans Regia L.) ve Mahun (Khaya Sp.) Odunlarının Yüzey Pürüzlülüğüne Etkileri”, İstanbul Üniversitesi Orman Fakültesi Dergisi, 55(2), 123136.

[45] Budakçı, M., Ilçe, A. C., Korkut, D. S., Gürleyen, T. 2011. "Evaluating the surface roughness of heat-treated wood cut with different circular saws”, BioResources, 6(4), 4247-4258.

[46] Kılıç, Y., Demirci, S. 2003. "Sarıçam ve Kestane Odunlarının Yüzey Pürüzlülük Değerlerinin Araştırılması”, GÜ Fen Bilimleri Dergisi, 16(3): 553-558.

[47] Örs, Y., Demirci, S. 1999. "Daire Testerelerde; Diş Sayısı, Kesiş Yönü ve Besleme Hızının Ağaç Malzeme Yüzey Düzgünlüğüne Etkileri”, Politeknik Dergisi, 2, 1-5.

[48] Ťavodová, M., Krilek, J., Perec, A., Kalincova, D., Kovac, J. 2016. "Analysis of the wear of saw blade teeth and the proposal of methods of increasing their wear resistance”, Modern Machinery Science Journal, (5), 1287-1291.

[49] Krilek, J., Kováč, J., Kučera, M. 2014. "Wood crosscutting process analysis for circular saws”, BioResources, 9(1), $1417-1429$.

[50] Cristóvão, L., Ekevad, M., Grönlund, A. 2013. "Industrial Sawing of Pinus Sylvestris L.: Power Consumption”, BioResources, 8(4), 6044-6053.

[51] Siklienka, M., Mišura, L., Hajník, I. 2007. "Influence of The Chosen Factors on The Cutting Power in Wood Processing by Circular Saw", In Proceedings of the 2nd International Scientific Conference Woodworking Technique, Zalesina, Croatia, 11-15 September, 295-302.

[52] De Souza, E. M. 2009. "Influence of The Woodworkability Parameters of Eucalyptus Sp. Wood in Specific Energy Consumption for Cutting in Circular Saw”, Master Thesis, Universidade Federal de Lavras, Brasil.

[53] Kminiak, R., Kubš, J. 2016. "Cutting power during cross-cutting of selected wood species with a circular saw”, BioResources, 11(4), 10528-10539. 
Nevşehir Bilim ve Teknoloji Dergisi (2019), 8(2) 114-124

[54] Nasir, V., Mohammadpanah, A., Cool, J. 2018. "The effect of rotation speed on the power consumption and cutting accuracy of guided circular saw: Experimental measurement and analysis of saw critical and flutter speeds", Wood Material Science \& Engineering, 1-7.

[55] Nasir, V., Cool, J. 2018. “A review on wood machining: characterization, optimization, and monitoring of the sawing process” Wood Material Science \& Engineering, 1-16.

[56] Oertli, 2018. “Circular Saws Catalogue”, Werkzeuge AG, Hofstrasse, Germany

[57] EDN, 2017. “Catalogue 45 Circular Saw Blades”, Ernst D. Neuhaus GmbH \& Co. KG., Cronenberg, Germany.

[58] URL-3: https://makezine.com/2016/09/15/understanding-saw-blade-essentials/ (Erişim tarihi: 22.09.2019).

[59] Kvietková, M., Gaff, M., Gašparík, M., Kminiak, R., Kriš, A. 2015. "Effect of number of saw blade teeth on noise level and wear of blade edges during cutting of wood”, BioResources, 10(1), 1657-1666. 